\title{
Peran Kualitas Pelayanan Terhadap Loyalitas Pelanggan Jasa Transportasi Online
}

\author{
Ingga Widi Aprilla $^{1^{*}}$ dan Sholihati Amalia ${ }^{2}$ \\ ${ }^{1}$ Jurusan Administrasi Niaga, Politeknik Negeri Bandung, Indonesia \\ ${ }^{2}$ Jurusan Administrasi Niaga, Politeknik Negeri Bandung, Indonesia
}

\begin{abstract}
:
Service quality is a form of activity undertaken by a company that aims to meet the wants and needs of customers by providing good service. Customer loyalty is a consumer's assessment of the quality of the product or service it receives based on existing expectations in the mind. Loyal customers will always tend to only one brand even though there are many similar brands. Sample in this study amounted to 135 respondents, is the people of Bandung who have or often use online transportation. The sampling technique using simple random sampling. The purpose of this study is to find out the influence of service quality on online transportation customer loyalty. The result obtained shows that service quality influence significantly customer loyalty by $24,1 \%$.
\end{abstract}

Keywords: service quality, customer loyalty, online transportation

\begin{abstract}
Abstrak:
Kualitas layanan adalah suatu bentuk kegiatan yang dilakukan oleh perusahaan yang bertujuan untuk memenuhi keinginan dan kebutuhan pelanggan dengan memberikan layanan yang baik. Loyalitas pelanggan adalah penilaian konsumen terhadap kualitas produk atau layanan yang diterimanya berdasarkan harapan yang ada dalam pikiran. Pelanggan setia akan selalu cenderung kepada satu merek meskipun ada banyak merek serupa. Sampel dalam penelitian ini berjumlah 135 responden, merupakan masyarakat Bandung yang pernah atau sering menggunakan transportasi online. Teknik pengambilan sampel menggunakan simple random sampling. Tujuan dari penelitian ini adalah untuk mengetahui pengaruh kualitas layanan terhadap loyalitas pelanggan transportasi online. Hasil yang diperoleh menunjukkan bahwa kualitas layanan berpengaruh signifikan terhadap loyalitas pelanggan sebesar $24,1 \%$.
\end{abstract}

Kata Kunci: kualitas layanan, loyalitas pelanggan, transportasi online

\section{Pendahuluan}

Transportasi merupakan suatu elemen yang memiliki pengaruh penting dalam kehidupan masyarakat modern. Transportasi juga merupakan sarana yang sangat penting dalam memperlancar perekonomian suatu daerah. Pentingnya transportasi baik darat, laut maupun udara ini tercermin pada semakin meningkatnya kebutuhan akan jasa angkutan bagi mobilitas orang serta barang. Transportasi merupakan hal yang lumrah ditemukan di banyak tempat. Hampir di seluruh wilayah Indonesia memiliki alat transportasi yang saling menghubungkan satu tempat dengan tempat lainnya. 
Pentingnya transportasi bagi masyarakat Indonesia disebabkan oleh bebarapa faktor, seperti faktor geografis Indonesia yang terdiri dari ribuan pulau, yang memungkinkan pengangkutan dilakukan melalui darat, udara, maupun perairan untuk menjangkau seluruh wilayah Indonesia. Di sisi lain kemajuan teknologi yang berupa internet semakin hari makin canggih dan banyak orang Indonesia memanfaatkannya. Hal tersebut juga menjadi salah satu faktor yang dapat mengubah gaya hidup masyarakat Indonesia menjadi berbasis teknologi. Dapat dilihat dari hasil laporan menurut Asosiasi Penyedia Jasa Internet Indonesia (APJII) pada Gambar 1.

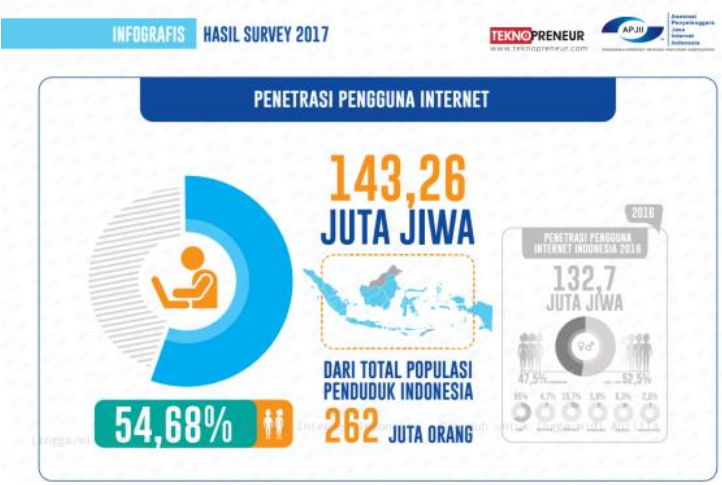

Gambar 1. Jumlah Pengguna Internet Indonesia Tahun 2017

Pada tahun 2017 pengguna internet di Indonesia mencapai 143,26 juta dari total populasi 252,4 juta orang, sedangkan pada tahun 2016 pengguna internet di Indonesia mencapai 132,7 juta pengguna dari total populasi penduduk 262 juta, sehingga diketahui bahwa jumlah pengguna internet di Indonesia mengalami peningkatan sebesar 10,56 juta orang. Dari data diatas dapat disimpulkan bahwa pengguna internet di Indonesia setiap tahun selalu bertambah, dan dapat dikatakan bahwa tingginya kebutuhan masyarakat Indonesia terhadap internet. Meningkatnya pengguna internet di Indonesia menghadirkan adanya jasa transportasi online di Indonesia yang tujuannya adalah untuk mempermudah pemesanan serta memberikan pelayanan dan keamanan terbaik bagi para penggunanya.

Setelah terbukti bahwa kecanggihan teknologi dimanfaatkan oleh pelaku bisnis transportasi untuk memadukan kecanggihan internet dengan menjadikan transportasi secara online yang dapat menjadi alternatif pilihan transportasi bagi masyarakat Indonesia, seperti yang dilakukan oleh PT Go-Jek Indonesia. PT Go-Jek Indonesia merupakan perusahaan yang menyediakan jasa transportasi online pertama di Indonesia. Bagi masyarakat Indonesia yang ingin menggunakan jasa Go-jek dapat menggunakannya pada smartphone, iphone, maupun ios. Sampai saat ini Go-jek sudah memiliki 17 layanan jasa yang diberikan yaitu dapat dilihat pada Gambar 1.3. Namun jenis layanan yang akan di survey dalam penelitian ini adalah layanan jasa Go-Car. Go-Car merupakan layanan antar jemput penumpang dari tempat penjemputan ke tempat tujuan dengan menggunakan mobil pribadi.

Jasa transportasi online memiliki beberapa keunggulan yang tidak dimiliki oleh transportasi konvensional, seperti biaya/ongkos perjalanan yang diberikan lebih murah, karena sudah terstandar dari perusahaan. Konsumen tidak perlu menunggu dipinggir jalan dengan waktu yang lama, serta adanya rasa aman bagi konsumen yang menggunakan jasa transportasi online dibandingkan dengan transportasi konvensional. Hal ini dikarenakan para pengemudi transportasi online berada di bawah naungan mitra perusahaan yang legal.

Kondisi transportasi umum di Indonesia kini sudah kurang memberikan kualitas serta layanan yang baik. Berdasarkan hasil pengamatan, banyak masyarakat yang mengeluh mengenai pelayanan transportasi konvensional seperti angkutan antar kota (angkot) dan ojek konvensional. Kualitas dan layanan yang diberikan oleh transportasi konvensional sudah semakin menurun, seperti kondisi angkot yang tidak layak jalan untuk mengangkut penumpang masih banyak beredar, lamanya angkutan umum yang sedang ngetem untuk menunggu penumpang, angkutan umum yang kadang berhenti sembarangan, atau angkutan umum yang selalu membawa kendaraan dengan ugal-ugalan, sehingga tidak sedikit masyarakat merasa kecewa dengan pelayanannya.

Selain itu, sudah terdapat beberapa kasus supir transportasi umum angkot yang mencabuli penumpangnya, pencurian di dalam angkot, supir yang mabuk sehingga terjadi kecelakaan, dan masih 
banyak kasus-kasus lainnya.Dengan banyaknya kasus-kasus yang terjadi didalam angkutan umum menjadi salah satu alasan mengapa masyarakat Indonesia enggan untuk menggunakan transportasi konvensional. Pilihan masyarakat yang berpindah ke jasa transportasi online yang dirasa sangat membantu masyarakat Indonesia, terlebih lagi dengan harga yang murah, nyaman dan keamanan yang diinginkan oleh masyarakat modern saat ini. Pada kenyataannya respon masyarakat Indonesia positif dan lebih memilih transportasi online dibandingkan dengan angkutan umum yang konvensional. Menurut Jawa Pos.com yang diterbitkan pada tanggal 14 Februari 2018, berdasarkan analisis Data Consumer Pulse yang di analisa oleh Ecommerce IQ, lembaga riset market di Asia Tenggara menunjukan bahwa 250 juta orang Indonesia dengan cepat mengadaptasi pertumbuhan transportasi berbasis aplikasi (taksi dan ojek online) untuk memudahkan hidup mereka.

Dengan adanya transportasi online yang dinilai dapat memudahkan, namun terdapatkejadian dari perusahaan salah satu transportasi online memiliki keamanan yang kurang menjamin keselamatan penumpangnya. Sudah banyak berita mengenai kurangnya keamanan yang diberikan oleh para driver transportasi online yang pada akhirnya dapat merugikan korban dan sampai merenggut nyawa korban. Berdasarkan latar belakang di atas, tujuan penelitian ini adalah untuk mengetahui: (1) tingkat loyalitas pelanggan terhadap jasa transportasi online, (2) pengaruh kualitas pelayanan jasa terhadap loyalitas pelanggan jasa transportasi online.

\section{Kajian Literatur}

\subsection{Kualitas Pelayanan}

Menurut Sembiring (2014: 3) kualitas pelayanan yaitu memberikan kesempurnaan pelayanan yang dilakukan oleh penyedia layanan dalam memenuhi kebutuhan dan keinginan pelanggan serta ketepatan penyampaiannya untuk mengimbangi harapan pelanggan. Sedangkan Supranto (2006) kualitas pelayanan adalah sebuah kata yang bagi penyedia jasa merupakan sesuatu yang harus dikerjakan dengan baik.

Kualitas pelayanan atau kualitas jasa berkaitan dengan kemampuan suatu organisasi untuk memenuhi atau melebihi harapan pelanggan, menurut Payne dalam Haryono (2010: 3). Menegaskan bahwa realitas adalah persepsi, Payne menyatakan bahwa ukuran kinerja adalah kualitas pelayanan atau jasa yang dipersepsikan. Terdapat dua komponen mengenai kualitas jasa menurut Payne:

1. Kualitas teknis, yaitu dimensi hasil proses operasi jasa.

2. Kualitas fungsional, yaitu dimensi proses dalam hal interaksi antara pelanggan dengan penyedia jasa.

Menurut Horsu \& Yeboah (2015) menyatakan bahwa model RECSA yang dikembangkan oleh McKnight et al (1986) dapat menjadi alat yang efektif untuk mengukur kualitas pelayanan jasa di jasa transportasi. Adapun dimensi dalam model RECSA dapat dilihat pada Gambar 2.

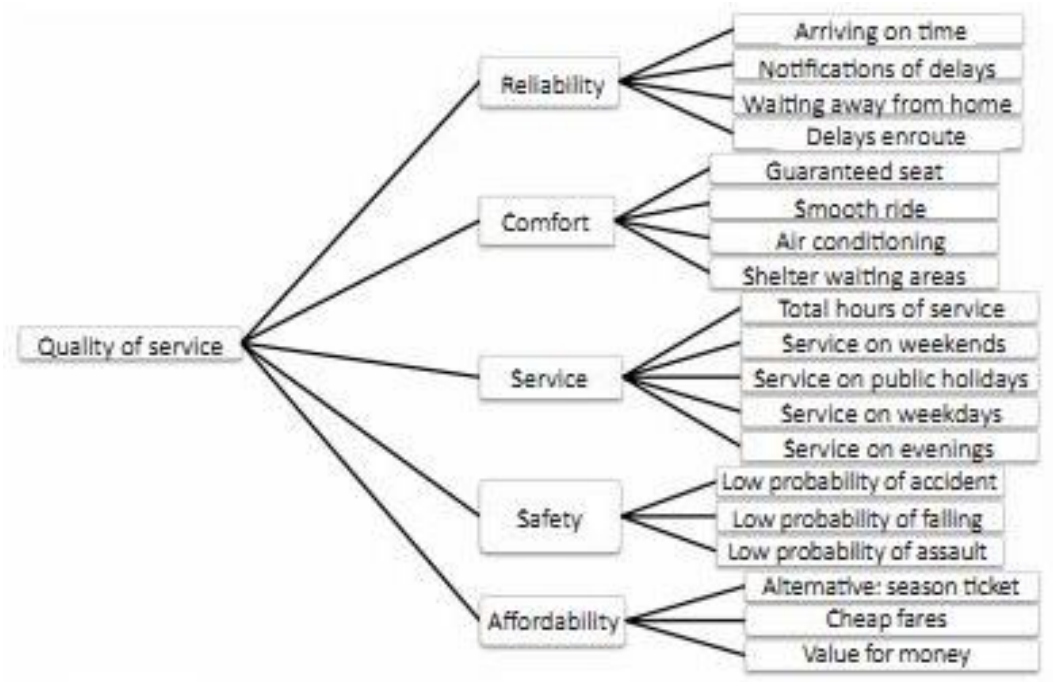

Gambar 2. Model RECSA 


\subsection{Loyalitas Pelanggan}

Secara harafiah loyal berarti setia, sehingga loyalitas diartikan sebagai kesetiaan yang timbul tanpa adanya paksaan, tetapi timbul dari kesadaran sendiri. Menurut Hurriyati (2005: 128), loyalitas pelanggan adalah komitmen pelanggan bertahan secara mendalam untuk berlangganan kembali atau melakukan pembelian ulang produk/jasa terpilih secara konsisten di masa yang akan datang, meskipun pengaruh situasi dan usaha-usaha pemasaran mempunyai potensi untuk perubahan perilaku.

Sedangkan loyalitas menurut Griffin (2005: 4) adalah lebih mengacu pada wujud perilaku dari unit-unit pengambilan keputusan untuk melakukan pembelian secara terus menerus terhadap barang atau jasa suatu perusahaan yang dipilih. Sedangkan menurut Dejawata dkk (2014: 4) menyebutkan bahwa loyalitas pelanggan adalah sikap pelanggan yang merasa puas atas barang atau jasa terpilih yang dikonsumsinya dan akan melakukan pembelian ulang di masa yang akan datang. Pembelian ulang tersebut berdasarkan sikap positif dan komitmen yang dimiliki pelanggan terhadap perusahaan yang ditunjukkan dengan merekomendasikan pada orang lain untuk membeli.

Sedangkan menurut Tjiptono (2015: 209) menyatakan bahwa pelanggan yang loyal pada merek tertentu cenderung "terikat" pada suatu merek dan akan membeli produk yang sama lagi meskipun tersedia banyak alternatif merek lainnya. Griffin dalam Sangadji dan Sopiah (2013:104) menyebutkan bahwa konsep loyalitas pelanggan lebih banyak dikaitkan dengan perilaku (behavior) daripada dengan sikap.

Griffin (2005: 31) menyebutkan karakteristik pelanggan yang loyal adalah sebagai berikut:

1. Melakukan pembelian ulang secara teratur (makes regular repeat purchase), yaitu konsumen melakukan pembelian secara berkala pada suatu produk atau jasa tertentu.

2. Membeli antar lini produk atau jasa (purchase across product and service lines), yaitu konsumen tidak hanya membeli satu jenis produk atau jasa, tetapi konsumen juga membeli produk atau jasa yang lain dari perusahaan yang sama.

3. Merekomendasikan kepada orang lain (refers others), yaitu dimana konsumen melakukan komunikasi dari mulut ke mulut (word of mouth) berkenaan dengan produk atau jasa tersebut.

4. Menunjukkan kekebalan terhadap tarikan dari pesaing (demonstrates immunity to the pull of the competition), yaitu konsumen menolak untuk menggunakan produk atau jasa alternatif yang ditawarkan oleh pesaing.

\subsection{Pengaruh Kualitas Pelayanan Terhadap Pelanggan}

Dalam menciptakan pelanggan yang loyal terhadap barang atau jasa yang dimiliki oleh suatu perusahaan, perusahaan harus mampu memberikan pelayanan serta kualitas yang baik bagi para pelanggan. Menurut McKnight et al (1986) menyatakan bahwa salah satu tantangan yang dihadapi oleh organisasi yang bergerak dalam bidang pelayanan transportasi adalah bahwa pengukuran kualitas pelayanan khususnya di bidang transportasi sangat sulit. McKnight et al mengembangkan dimensi kualitas pelayanan yang dikemukakan oleh Parasuraman et al (1988), RECSA model sebagai alat ukur yang efektif untuk mengukur kualitas layanan dalam jasa transportasi. Adapun dimensi dari RECSA model adalah reliability, comfort, service, safety, dan affordaniliy.

Pada dasarnya tujuan akhir dari suatu perusahaan adalah untuk memberikan kepuasan terhadap pelanggan mengenai barang atau jasa yang ditawarkan. Pelanggan yang merasa puas oleh barang atau jasa tersebut menjadi modal dasar bagi perusahaan. Perusahaan yang memberikan kualitas serta pelayanan yang baik akan memberikan kepuasan terhadap pelanggan, dimana hal tersebut dapat bermanfaat juga untuk menjalin hubungan yang harmonis antara perusahaan dan pelanggan, sehingga pada akhirnya dapat terjadi timbal balik yang baik antara perusahaan dengan pelanggan. Pelanggan yang merasa puas terhadap kualitas dan layanan yang diberikan perusahaan akan melakukan keputusan untuk melakukan pembelian ulang, merekomendasikan merek kepada orang lain dan tetap memilih Go-jek dibandingkan jasa transportasi lain.

\subsection{Hipotesis Penelitian}

Berdasarkan pembahasan dalam pendahuluan dan landasan teori, maka formulasi hipotesis yang diajukan untuk diuji kebenarannya dalam penelitian ini, yaitu: 

pelanggan transportasi online.

Ha : Ada pengaruh yang signifikan

antara kualitas layanan terhadap loyalitas pelanggan transportasi online.

\section{Metode Penelitian}

Penelitian ini masuk kedalam kategori jenis penelitian parametrik dengan pendekatan deskriptif kuantitatif yang tujuannya adalah untuk mendapatkan data yang valid dengan tujuan dapat ditemukan, dikembangkan, dan dibuktikan, suatu pengetahuan tertentu sehingga dapat digunakan untuk memahami, memecahkan dan mengantisipasi masalah (Sugiyono, 2012).

Populasi dalam penelitian ini adalah pelanggan transportasi online yang pernah menggunakan layanan jasa transportasi online minimal sebanyak dua kali di Kota Bandung. Besaran populasi dalam penelitian ini tidak diketahui, hal tersebut karena tidak tersedianya sumber data yang dapat digunakan sebagai referensi. Hair et al dalam Prawira (2010) merekomendasikan apabila populasi penelitian tidak diketahui, jumlah sampel minimal adalah 5 kali dari jumlah pertanyaan yang terdapat dalam kuesioner. Jumlah pertanyaan dalam penelitian ini adalah 27 , sehingga minimal ukuran sampel dalam penelitian ini adalah: 27 x $5=135$ sampel. Metode pengambilan sampel yang digunakan adalah metode non probability sampling.

Metode pengumpulan yang digunakan dalam penelitian ini menggunakan kuesioner. Bentuk pengukuran skala yang digunakan dalam penelitian ini yaitu menggunakan skala likert. Alat ukur kualitas pelayanan mengacu pada teori yang dikemukakan oleh McKnight et al (1986) mengenai lima dimensi kualitas pelayanan. Adapun alat ukur loyalitas pelanggan mengacu pada teori yang dijelaskan oleh Griffin (2005) mengenai empat karakteristik dari pelanggan yang loyal.

Uji validitas batas minimal untuk dikatakan bahwa indikator tersebut valid adalah 0,3 sesuai dengan pendapat yang dikemukakan oleh Sugiyono (2012) yang mengatakan bahwa syarat minimum untuk item dikatakan valid jika memenuhi syarat adalah $\mathrm{r} \geq 0,3$. Uji reliabilitas pada penelitian ini menggunakan Alpha Cronbachdimana penilaiannya adalah keandalan $<0,60$ dianggap buruk, keandalan dalam kisaran 0,70 bisa diterima dan $>0,80$ adalah baik. Uji normalitas dilakukan menggunakan teknik Kolmogorov Smirnov Test. Data dapat dikatakan normal apabila p >0,05. Untuk mendapatkan gambaran mengenai subjek penelitian, dilakukan statistika deskriptif dengan menentukan presentase.

Untuk melihat pengaruh kualitas pelayanan terhadap loyalitas pelanggan menggunakan regresi linier sederhana. Untuk mengetahui seberapa besar pengaruh variabel independent terhadap variabel dependent dapat dilihat pada nilai koefisien determinasi.Nilai $\mathrm{R}$ square yang kecil berarti kemampuan variabel-variabel bebas dalam menjelaskan variasi variabel dependent sangat terbatas. Nilai yang mendekati satu memiliki arti bahwa variabel independent memberikan hampir semua informasi yang dibutuhkan untuk memprediksi variasi variabel dependent.

\section{Hasil dan Pembahasan}

\subsection{Identitas Responden}

Tabel 1 menunjukan mengenai identitas responden dalam penelitian ini.

Tabel 1. Identitas Responden

\begin{tabular}{|c|l|r|r|}
\hline Identitas & \multicolumn{1}{|c|}{$\begin{array}{c}\text { Kete- } \\
\text { rangan }\end{array}$} & $\begin{array}{c}\text { Res- } \\
\text { ponden }\end{array}$ & \multicolumn{1}{l|}{} \\
\hline \multirow{3}{*}{$\begin{array}{c}\text { Jenis } \\
\text { Kelamin }\end{array}$} & Perempuan & 90 & 67 \\
\cline { 2 - 4 } & Laki-laki & 45 & 33 \\
\hline \multirow{3}{*}{ Usia } & $<18$ & 12 & 9 \\
\cline { 2 - 4 } & $19-25$ & 89 & 5 \\
\cline { 2 - 4 } & $26-35$ & 27 & 66 \\
\cline { 2 - 4 } & $>36$ & 7 & 20 \\
\hline Pekerjaan & PNS & 6 & 4 \\
\hline
\end{tabular}




\begin{tabular}{||l|l|r|r|}
\hline \multirow{5}{*}{} & Pegawai & 28 & 21 \\
\cline { 2 - 4 } Swasta & Wiraswasta & 14 & 10 \\
\cline { 2 - 4 } & TNI/Polri & 2 & 2 \\
\cline { 2 - 4 } & Mahasiswa & 62 & 46 \\
\cline { 2 - 4 } Frekuensi & Pelajar & 11 & 8 \\
\cline { 2 - 4 } & Lainnya & 12 & 9 \\
\hline \multirow{3}{*}{ 1 kali } & - & 0 \\
\cline { 2 - 4 } & $2-5$ kali & 34 & 25 \\
\cline { 2 - 4 } & $>5$ kali & 101 & 75 \\
\hline
\end{tabular}

\subsection{Kualitas Pelayanan}

Variabel kualitas pelayanan memiliki rata-rata jawaban sebesar 3,92, yang berada pada skala interval 3,40-4,19 dan masuk kedalam kategori baik. Nilai standar deviasi variabel kualitaas pelayanan berada dibawah $20 \%$ yakni sebesar $18,01 \%$, yang artinya bahwa mayoritas responden menjawab pertanyaan pada variabel kualitas pelayanan dengan jawaban yang relatif sama. Dimensi dengan nilai rata-rata paling rendah adalah dimensi safety, sedangkan nilai rata-rata paling tinggi pada variabel kualitas pelayanan terdapat pada dimensi service sebesar 4,24. Tabel 2 merupakan pemaparan dari kedua dimensi tersebut.

Tabel 2. Analisis Deskriptif Kualitas Pelayanan

\begin{tabular}{|l|l|l|l|}
\hline & N & \multicolumn{1}{|c|}{ Mean } & \multicolumn{1}{|c|}{$\begin{array}{c}\text { Std. } \\
\text { Dev }\end{array}$} \\
\hline Service & 135 & 4,24 & 0,596 \\
\hline Safety & 135 & 3,54 & 0,796 \\
\hline Kualitas Pelayanan & 135 & 3,92 & 0,706 \\
\hline
\end{tabular}

\subsection{Loyalitas Pelanggan}

Variabel loyalitas pelanggan memiliki nilai rata-rata jawaban sebesar 3,49, yang berada pada skala interval 3,40-4,19 dan masuk kedalam kategori baik. Nilai standar deviasi variabel kualitaas pelayanan berada diatas $20 \%$ yakni sebesar $23,86 \%$, yang artinya bahwa mayoritas responden menjawab pertanyaan pada variabel loyalitas pelanggan dengan jawaban yang cukup beragam. Dimensi dengan nilai rata-rata paling rendah adalah dimensi immunity of the competition dengan nilai rata-rata 3,07, sedangkan nilai rata-rata paling tinggi pada variabel loyalitas pelanggan terdapat pada dimensi purchase product and service lines sebesar 3,87. Tabel 3 merupakan pemaparan dari kedua dimensi tersebut.

Tabel 3. Analisis Deskriptif Loyalitas Pelanggan

\begin{tabular}{|l|c|l|l|}
\hline & N & Mean & $\begin{array}{c}\text { Std. } \\
\text { Dev }\end{array}$ \\
\hline Purchase Product and Service Lines & 135 & 3,87 &, 763 \\
\hline Immunity of the Competition & 135 & 3,07 &, 915 \\
\hline Loyalitas Pelanggan & 135 & 3,49 &, 833 \\
\hline
\end{tabular}

\subsection{Analisis Korelasi dan Regresi}

Berdasarkan Tabel 5 diperoleh konstanta sebesar 8,562 dan koefisien regresi sebesar 0,568. Apabila dimasukan kedalam rumus persamaan regresi maka diperoleh hasil sebagai berikut: $Y=8,562+0,568 \mathrm{X}$. Tanda positif pada koefisien regresi $\mathrm{b}$ memiliki arti jika penambahan satu pada $\mathrm{X}$, maka mampu meningkatkan Y sebesar 0,568. Jika variabel kualitas pelayanan ditingkatkan maka variabel loyalitas pelanggan akan meningkat juga, dan juga sebaliknya. 
Tabel 4. Analisis Korelasi

\begin{tabular}{|c|c|c|c|}
\hline & & VAR_X & VAR_Y \\
\hline \multirow{3}{*}{ VAR_X } & Pearson Correlation & 1 & $0,491^{* *}$ \\
\hline & Sig. (2-tailed) & & 0,000 \\
\hline & $\mathrm{N}$ & 135 & 135 \\
\hline \multirow{3}{*}{ VAR_Y } & Pearson Correlation & $0,491^{* *}$ & 1 \\
\hline & Sig. (2-tailed) & 0,000 & \\
\hline & $\mathrm{N}$ & 135 & 135 \\
\hline
\end{tabular}

Tabel 5. Analisis Regresi Linier Sederhana

\begin{tabular}{|l|l|l|l|l|l|l|}
\hline \multirow{2}{*}{ Model } & \multicolumn{2}{|l|}{$\begin{array}{l}\text { Unstandardized } \\
\text { Coefficients }\end{array}$} & $\begin{array}{l}\text { Standardized } \\
\text { Coefficients }\end{array}$ & t & Sig. \\
\cline { 3 - 5 } \multicolumn{2}{|l|}{} & B & Std. Error & Beta & & \\
\hline \multirow{2}{*}{1} & (Constant) & 8,562 & 5,161 & & 1,659 & 0,099 \\
\cline { 2 - 6 } & VAR_X & 0,568 & 0,087 & 0,491 & 6,506 & 0,000 \\
\hline
\end{tabular}

Tabel 6. Koefisien Determinasi

\begin{tabular}{l|l|l|l|l|}
\hline Model & R & R Square & Adjusted R Square & Std. Error of the Estimate \\
\hline 1 &, $491^{\text {a }}$ &, 241 &, 236 & 6,145 \\
\hline
\end{tabular}

Nilai $R$ Square pada Tabel 6 yaitu sebesar 0,241 atau 24,1\%. Hal ini menunjukan bahwa variabel kualitas pelayanan memiliki pengaruh sebesar $24,1 \%$ terhadap loyalitas pelanggan, dan $75,9 \%$ dipengaruhi oleh factor lain yang tidak diteliti dalam penelitian ini, menurut Gaffar (2007) loyalitas pelanggan dipengaruhi oleh kepuasan (satisfaction), ikatan emosi (emotional bonding), kepercayaan (trust), kemudahan (choice reduction and habit), dan pengalaman dengan perusahaan (history with company).

\subsection{Uji Hipotesis}

Berdasarkan Tabel 7 dilihat bahwa nilai $\mathrm{F}_{0}$ sebesar 42,331 dengan Sig. 0,000.Dengan menggunakan tingkat signifikan 0,05 serta $\mathrm{df}_{1}:(\mathrm{k}-1)=2-1=1$ dan $\mathrm{df}_{2}:(\mathrm{n}-\mathrm{k})=135-2=133$, maka diperoleh $\mathrm{F}$ tabel $\left(F_{1}\right)$ sebesar 3,91 yang berarti bahwa nilai $F_{0} \geq F_{1}$ yaitu $42,331 \geq 3,91$.jika kriteria $F_{0} \geq F_{1}$ dengan taraf signifikansi $5 \%$ maka interpretasinya adalah $\mathrm{H}_{\mathrm{o}}$ ditolak dan $\mathrm{H}_{\mathrm{a}}$ diterima. Hal tersebut menunjukan bahwa kualitas pelayanan berpengaruh secara positif dan signifikan terhadap loyalitas pelanggan pengguna jasa transportasi online.

Tabel 7. Uji Statistik F

\begin{tabular}{|c|c|c|c|c|c|c|}
\hline \multicolumn{2}{|c|}{ Model } & Sum of Squares & $\mathrm{df}$ & Mean Square & $\mathrm{F}$ & Sig. \\
\hline \multirow{3}{*}{1} & Regression & 1598,483 & 1 & 1598,483 & 42,331 & $0,000^{b}$ \\
\hline & Residual & 5022,332 & 133 & 37,762 & & \\
\hline & Total & 6620,815 & 134 & & & \\
\hline
\end{tabular}

Berdasarkan Tabel 8 dilihat bahwa nilai t hitung sebesar 6,506 dengan nilai Sig. 0,000. Sedangkan nilai $\mathrm{t}$ tabel dengan rumus $\mathrm{df}=$ jumlah data -1 atau sebesar $135-1=134$, maka diperoleh $\mathrm{t}$ tabel 1,977. Berdasarkan data tersebut, diperoleh nilai t hitung yang lebih besar dari $t$ tabel $(6,506>1,977)$. Maka dapat disimpulkan bahwa $\mathrm{H}_{0}$ ditolak dan $\mathrm{H}_{\mathrm{a}}$ diterima. Hal tersebut menunjukan bahwa kualitas pelayanan berpengaruh secara positif dan signifikan terhadap loyalitas pelanggan pengguna jasa transportasi online. 
Tabel 8. Uji Statistik t

\begin{tabular}{|l|l|l|l|l|l|l|}
\hline \multirow{2}{*}{ Model } & \multicolumn{2}{|l|}{$\begin{array}{l}\text { Unstandardized } \\
\text { Coefficients }\end{array}$} & $\begin{array}{l}\text { Standardized } \\
\text { Coefficients }\end{array}$ & \multirow{2}{*}{ T } & \multirow{2}{*}{ Sig. } \\
\cline { 3 - 5 } \multicolumn{2}{|l|}{} & B & Std. Error & Beta & & \\
\hline \multirow{2}{*}{1} & $($ Constant $)$ & 8,562 & 5,161 & & 1,659 & 0,099 \\
\cline { 2 - 5 } & VAR_X & 0,568 & 0,087 & 0,491 & 6,506 & 0,000 \\
\hline
\end{tabular}

\section{Kesimpulan dan Saran}

Berdasarkan hasil pengumpulan data, pengolahan serta analisis data yang telah dilakukan, berikut merupakan kesimpulan yang menjawab perumusan masalah pada penelitian ini:

1. Kualitas pelayanan yang diberikan oleh driver pelanggan transportasi online termasuk ke dalam kategori penilaian baik.

2. Loyalitas pelanggan layanan transportasi online termasuk dalam kategori penilaian baik.

3. Terdapat adanya pengaruh positif dan signifikan dari kualitas pelayanan terhadap loyalitas pelanggan pada pengguna jasa transportasi online. Adapula besarnya pengaruh kualitas pelayanan terhadap loyalitas pelanggan pengguna jasa transportasi online yaitu sebesar $24,1 \%$, sementara $75,9 \%$ dipengaruhi oleh faktor-faktor lain yang tidak dijelaskan dalam penelitian ini.

Kualitas pelayanan pada pengguna jasa transportasi online pada dasarnya dirasa sudah cukup baik oleh para pelanggan, namun ada beberapa saran untuk meningkatkan kualitas pelayanan agar lebih baik lagi, agar dapat meningkatkan serta mempertahankan loyalitas dari para pelanggan layanan transportasi online:

1. Sebaiknya pihak manajemen dapat meningkatkan kualaitas pelayanan dari segi kemanannya dengan cara nambah satu tahap porses rekruitmen yaitu adanya tahap psikotes seperti tes kepribadian, mental, atau sikap, tujuannya adalah untuk menyaring calon mitra yang sesuai dengan ketentuan perusahaan, atau bisa juga dengan cara ATM (amati, tiru, dan modifikasi) fitur emergency yang ada pada aplikasi lain. Cara kerja fitur emergency ini adalah ketika penumpang melihat situasi berbahaya ketika mengendarai transportasi online dapat langsung terhubung sama teman atau kerabatnya. Tujuan fitur ini adalah untuk penumpang merasa lebih aman ketika dalam perjalanan.

2. Pihak manajemen sebaiknya memberi berbagai promosi yang ditawarkan sehingga pelanggan akan tetap loyal khususnya terhadap layanan transportasi online.

3. Pihak manajemen sebaiknya memperhatikan juga faktor-faktor lain yang dapat meningkatan loyalitas di luar penelitian ini, seperti faktor kepuasan, ikatan emosi, kepercayaan, kemudahan, dan pengalaman dengan perusahaan.

\section{Daftar Pustaka}

Dejawata, T. B., Kumadji, S., \& Abdillah, Y. 2014. Pengaruh Diferensiasi Produk Terhadap Kepuasan Pelanggan dan Loyalitas Pelanggan. Jurnal Administrasi (JAB) Vol. 17, No. 2 Desember 2014.

Gaffar, V. 2007. Manajemen Bisnis. Bandung: Alfabeta.

Griffin, J. 2005. Customer Loyalty, Edisi Revisi. Jakarta: Erlangga.

Haryono, S. 2010. Analisis Kualitas Pelayanan Angkutan Umum (Bus Kota) Di Kota Yogyakarta. Jurnal Administrasi Bisnis, Volume 7, No. 1 juli 2010.

Horsu, E. N., \& Yeboah, S. T. 2015. Influence of Service Quality on Customer Satisfaction: a Study of Minicab Taxi Services in Cape Coast, Ghana. International Journal of Economics, Commerce and Management, Vol.3, Issue 5, May 2015. ISSN 23480386.

Hurriyati, R. 2005. Bauran Pemasaran dan Loyalitas Konsumen. Bandung: Alfabeta. 
McKnight, C. E., Pagano, A. M and Paaswell, R. E. 1986. Using Quality to Predict Demand for Special Transportation, in Behavioral Research for Transport Policy. International Conference on Travel Behaviour. Noordwijk, The Netherlands, Utrecht: VNU Science Press.

Prawira, A. 2010. Metodelogi Penelitian Jilid 1. Jogyakarta: PT Grasindo.

Sangadji, E. M. \& Sopiah. 2013. Perilaku Konsumen: Pendekatan Praktis Disertai: Himpunan Jurnal Penelitian. Yogyakarta: Andi.

Sembiring, I. J. 2014. Pengaruh Kualitas Produk dan Kualitas Pelayanan Terhadap Kepuasan Pelanggan Dalam Membentuk Loyalitas Pelanggan (Studi pada Pelanggan McDonald's MT.Haryono Malang). Jurnal Administrasi Bisnis (JAB), Vol. 15, No. 1 Oktober 2014.

Sudaryono. 2014. Perilaku Konsumen Dalam Perspektif Pemasaran. Jakarta: Lentera Ilmu Cendekia. Sugiyono. 2012. Metode Penelitian Kuantitatif Kualitatif dan R\&D. Bandung: Alfabeta.

Supranto, J. 2006. Pengukuran Tingkat Kepuasan Pelanggan: Untuk Menaikkan Pangsa Pasar. Jakarta: Rineka Cipta.

Tjiptono, F. 2015 Strategi Pemasaran, Edisi 4. Yogyakarta: Andi.

\section{*Email Korespondensi:}

ingga.widi@gmail.com 